\title{
Collaborative Islamic Banking Service: The Case of Ijarah
}

\begin{abstract}
Karim Ullah ${ }^{1}$, Wafi Al-Karaghouli², Shafiullah Jan ${ }^{3}$
Abstract

This paper explores the collaborating roles of various service cocreators, within an auto Ijarah service, to establish how Islamic bank, customer, and supporting parties cocreate an Islamic banking service within a market, while using in depth narrative single case qualitative data analysis of an Ijarah manager and supporting documents. This collaborative perspective challenges the current dominant perspective of service being produced by the financial institutions alone. These findings enhance our understanding of how a holistic auto Ijarah service is cocreated by multiple parties within market. This is contrary to the prevailing assumption that an Ijarah is a product of an Islamic bank alone. This perspective can provoke thinking towards a more collaborative and trust building culture by forming a holistic Islamic banking community within market.
\end{abstract}

Keywords: Collaborating roles, Islamic banking, Ijarah.

\section{Introduction}

The current marketing literature emphasises on conceptualizing service as collaborative process where the value is cocreated by the service organization with and for customer (e.g., Vargo \& Lusch, 2004; Lusch \& Vargo, 2006; Vargo \& Akaka, 2012). This service perspective within marketing literature breaks the economics perspective of visualising service as produced by the organization and consumed by the customer. Rather they both co-create and co-consume the service and value within context (Lusch $\&$ Vargo, 2006). In this sense, a service can be conceptualised as inter-connected set of actions that multiple service providers undertake in direct interaction with customer (Grönroos, 2000). A service process is considered complete when set objectives are achieved (Sampson, 2012). This paper explores how this service cocreation happens within Islamic banking service.

1 Assistant Professor, Institute of Management Sciences, Peshawar. Email: karim.ullah@imsciences. edu.pk

2 Senior Lecturer, Brunel University, London. Email: Wafi.Al-Karaghouli@brunel.ac.uk

3 Assistant Professor, Institute of Management Sciences, Peshawar. Email: shafiullah.jan@imsciences. edu.pk

ARTICLE HISTORY
\begin{tabular}{lll}
$10 \mathrm{Nov}, 2016$ Submission Received & $6 \mathrm{Dec}, 2016$ & First Review \\
\hline $10 \mathrm{Jan}, 2017$ Revised Version Received & $7 \mathrm{Mar}, 2017$ & Second Review \\
\hline $24 \mathrm{Apr}, 2017$ Revised Version Received & $10 \mathrm{May}, 2017$ & Accepted
\end{tabular}


In Islamic banking service, the bankers apply Islamic finance models (IFMs) such as Shirkah, Bai, Ijarah, and Wakalah as plans of actions. These plans set objectives in terms of creating some mutual benefits such as making profit for bank and customers. IFMs specify different parties as service creators and their collaborating roles through which they create a service. IFMs primarily ensure Shari'ah compliance in the economic contracts or transactions, which occur in the service process. For instance, to avoid interest, which is prohibited in Shari'ah, the designers of these services replace conventional loan contracts with IFMs to create service (e.g., Ahmed, 2011; Ayub, 2008; Usmani, 2002; Vogel \& Hayes, 1998). The designers though make changes in the contracts, however, compliance to Shari'ah rarely reflects in the real service actions that emerge as consequence of these contracts (Dar \& Pressley, 1999; El-Gamal, 2008; Siddiqi, 2006), which can be termed as substance of the IFMs applied. This absence of Shari'ah compliance in substance happens mainly because the product development departments in Banks fail to completely visualize real collaborative services which are emergent and cannot be defined exactly in advance and can only be holistically conceptualized in multiple collaborations of organization, customer, and aiding parties in future.

IFMs are not purpose-built service models but are Islamic economic contracts adapted and applied to the banking service. To cover the collaboration roles of the multiple service cocreators, the practitioners apply multiple IFMs to create an Islamic banking service. This need of integrating multiple IFMs emerges because each IFM does not clearly define the collaborating roles of all service creators, customers, and other parties that collaborated during the practice. In general service literature, however, this is established that multiple parties co-create a service and the value through it (Maglio, Vargo, Caswell, \& Spohrer. 2009; Sampson, 2010; Vargo \& Lusch, 2004). Within a service cocreation process, each party assumes one or more roles to create actions, which constitute the holistic service (Sangiorgi, 2009). However, these arguments related to collaboration of multiple service creators are new for Islamic banking service. There is little evidence to show that an Islamic banking service is co-created by multiple service creators through collaboration, since IFMs provide little knowledge related to this aspect of the banking practice. We, therefore, theoretically and empirically investigate who or what parties participate in the creation of a holistic Islamic banking service and also how each party integrate its role(s) with other to enable the service creation process?

These questions are posted for two reasons. Firstly, the phenomenon service cocreation and cocreators is based on the general service literature and lacks empirical evidence in Islamic banking service, which this paper provides. Secondly, if the concept of service cocreation and collaboration of multiple service creators is evident 
in Islamic banking practice, then this can open a new and holistic perspective of looking to the Islamic banking products. This new service perspective can complement the current financial and jurisprudence perspectives to conceptualize and develop comprehensive Islamic service models.

This service cocreation perspective can clarify the roles of various participants in the Islamic financial system and in turn these roles can be better designed, implemented, and monitored for important management concerns such as time delays, cost of documentation, and regulating the Shari'ah compliance of the service. If a product design is based on the premise that it is collaboratively be produced in future, the participants are more likely to be more aware of the roles of each participant and its attached time, costs, documentation, and relevant regulations. This will enhance the effectiveness of overall management of the product compared to current approach of making one institution responsible for all roles whether the roles falling in its domain or not.

The rest of paper is organized as follows; next section briefly introduces the phenomenon of service cocreation and collaboration. After that the prominent IFMs are reviewed from the service cocreation perspective. Proceeding further, the research design and findings are reported. Finally, the paper is concluded, implications, and further research directions are pointed.

\section{Service Cocreation}

Islamic banks are, in essence, service organizations, which are producing intangible, heterogeneous, and highly perishable services (e.g., Ahmed, 2011; Ullah, 2014). In the contemporary service literature, this view is not complete because the service and the resulted value through it is considered co-created by the multiple parties including customer, service organization, and aiding systems (Maglio et al., 2009; Sampson, 2012; Vargo \& Lusch, 2004). In this sense, Islamic bankers and clients collaborate and co-create Islamic banking service because both contribute actions and usufructs of their resources that constitute service. The credit card service, for example, emerges as a set of collaborative actions and usufructs of resources of multiple entities such as payer-payee banks, client, visa system, and interbank ATM network. In conventional finance also this is common to add special services to the mainline services of bank such as landing (e.g., James, 1987) such integration and packaging of various services requires integrations of roles exist within multiple entities. These roles normally integrate when the participants have common value propositions to be realized.

The essence of service cocreation is multiple service systems and their integration and collaboration of resources and actions, which enables a holistic service that is 
objective oriented (Sampson, 2012). In Islamic banking service, also, the multiple systems integrate resources to co-create the service of Islamic banking. The IFMs bases on partnership, sale, lease, at least partially, define the roles of different Islamic banking service creators, however, there is need of a more in-depth analysis of the current IFMs and its application to draw-out more detailed collaborating roles that may exist in the actual Islamic banking service practice and are not explained in theory before. Next section provides a discussion of IFMs from the perspective of the extent to which these models acknowledge the collaborating roles of multiple entities in the creation of Islamic banking service.

\section{Islamic Finance Models}

A model is the representation of real practice. In this sense, partnerships, sales, lease, and other contracts are in essence models, which represent the real service practice that is created through its multiple applications in different contexts. There are various types of IFMs, which are applied by the Islamic banks to create their service. The first category is participatory models (Shirkah). A participatory model considers the Islamic bank and client as partners in producing economic benefits through a mechanism compliant to Shari'ah (Ayub, 2008; Iqbal \& Mirakhor, 2008; Usmani, 2002). Islamic banks use partnership models with different variations to fulfill their contextual needs. For example, Musharikah is used as joint enterprise in which all partners share the profit and loss of the venture (Usmani, 2002). However, the dominant form of partnership is the diminishing Musharikah in which the ownership shares of at least one collaborating partner gradually decreasing till that reaches to zero (Ayub, 2008). Another form of partnership, which is mostly used for creating depository service, is the Mudarabah, in which one partner, the depositor invest money whereas, the other, a bank, provides actions and thus co-create economic value (Ayub, 2008; Iqbal \& Mirakhor, 2008; Usmani, 2002).

Islamic banks also use sale models to create services such as working capital finance (Ullah, Jan, \& Khan, 2017; Iqbal \& Mirakhor 2008; Ahmad, Malik, \& Humayoun, 2010). Service cocreation also occurs in these sales models. For example, in Murabahah (cost plus sale) (e.g., Wilson, 2002) a bank, customer, and a vendor integrate their actions and resources to create service for each other, as they build on the actions and resources of each other. Other sales models such as Salam and Istisnah (e.g., Usmani, 2002) create service structures in which collaboration between bank and customer vary and thus make them enable to evolve into different service requirements (Ullah, 2014). For example, in construction or heavy machinery projects, banks use Istisna (order to manufacture model) (Ullah \& Al-Karaghouli, 2017).

Islamic banks also use Ijarah (lease) model to create service where the usufruct of 
mostly tangible and durable assets is provided to others in return for a rent (Ahmad et al., 2010; Iqbal \& Mirakhor, 2008; Usmani, 2002). In Ijarah a bank provides the asset on rent to customer, for example Auto Ijarah, in which a bank leases an auto to the customer. In Ijarah practice also, one can observe, that the Islamic bank, client, and supplier of autos, get together to complete the service process.

Many of the Islamic banking services, such as transfer of money, can be created through Wakalah (agency) model (Iqbal \& Mirakhor, 2008; Ullah \& Al-Karaghouli, 2017). In this model, though, normally a bank works as an agent of the customer, however, we can see that the customer him/her self and other corresponding banks and money receiving party also perform many actions that become part the service through which the ultimate objective of the money transfer is achieved. Table 1 summarizes various service cocreators and their collaborating roles in different IFMs.

Table 1: Service Co-creators' Roles in Islamic Finance Models

\begin{tabular}{|c|c|c|c|}
\hline & Islamic Finance Models & Service Cocreators & Roles \\
\hline 1. & Musharikah & Bank and Client & Capital Partners \\
\hline 2. & Diminishing Musharikah & $\begin{array}{c}\text { Bank, Client, Property } \\
\text { Seller }\end{array}$ & Capital Partners \\
\hline 3. & Mudarabah & Bank and Client & $\begin{array}{c}\text { Capital and Working } \\
\text { Partners }\end{array}$ \\
\hline 4. & Murabahah & $\begin{array}{c}\text { Bank, Client, Aiding } \\
\text { Party }\end{array}$ & $\begin{array}{c}\text { Seller. Buyer, and } \\
\text { Vendor }\end{array}$ \\
\hline 5. & Ijarah & $\begin{array}{c}\text { Bank, Client, Aiding } \\
\text { Party }\end{array}$ & $\begin{array}{c}\text { Lessor, Lessee, and } \\
\text { Vendor }\end{array}$ \\
\hline 6. & Wakalah & Bank and Client & Agent and Principal \\
\hline
\end{tabular}

In a nutshell, if we critically evaluate the actual application of IFMs to create service in different contexts, it is quite visible that in each application there is not just the bank, which performs actions and uses its resources; rather, the client also performs actions, which help (serve) the bank to initiate their actions. Also, supporting parties such as vendors and other corresponding banks also perform actions and use their resources to enable a holistic service and achieve specific objectives. In many cases, the bank can be seen integrating multiple IFMs to create a single service, this particularly, happens because in practice there are many parties in a service for which a single IFM does not provide sufficient structure. However, in theory of IFMs there is little knowledge on how this integration and collaboration of multiple parties happens. The questions posted in this paper seek answers to explore and conceptualize more holistic Islamic financial service that occurs through these collaborations and integrations. 


\section{Research Design}

A qualitative case study approach is used in this paper for empirical evaluation and further development of the phenomenon of service cocreation in Islamic banking. A case, as the term suggests, is a bounded and contextually established research strategy (Stoecker, 1991; Creswell, 2009) in which a researcher do analysis of focused case (Thomas, 2011). For the analysis to be effective, a researcher fixes a focused unit of analysis for which the data is to be collected and analysed. The focal unit of analysis can be an individual person, event, entity, decision, program, or an implementation process (Yin, 2003).

This research has selected an Islamic commercial bank (hereafter referred as the bank) as broad banking case unit within which an Ijarah case (hereafter referred the Ijarah) is selected an embedded unit of analysis. The Ijarah case is created in the recent past for auto lease. The case strategy is selected because it is considered an ideal research strategy for evaluating processes and events (Yin, 2003; Creswell, 2009). A service, such as the Ijarah service, is an integrated set of real temporal processes and events that are undertaken for achieving set objectives (Shostak, 1982; Chase \& Tansik, 1983).

In this study, the unit of analysis is real Ijarah case. Since the Ijarah service is created as a start to end temporal actions flows, so narrative format of interviewing is selected. Narrative means a cognitive process that organizes human experiences into temporally meaningful episodes (Polkinghorne, 1988). The narrative format enabled the researchers to generate knowledge about the real Ijarah service, in the sequence in which the actions flow proceeded in the real service. The analysis enabled us to find and highlight service creators and their roles not explained in the theory of Islamic finance.

A narrative format of interviewing is selected to gather in depth data in the form to complete a story of the actual Ijarah service that could provide in depth detail about different roles of service cocreators and how they collaborated during different episodes or encounters of the service. Narrative is an in depth qualitative interviewing process that involves intensive individual interviews of one or very few participants to achieve greater focus of the case (Boyce \& Neale, 2006). This approach is particularly useful to achieve a complete and in-depth detail of a program that is aimed to be explored (Boyce \& Neale, 2006). The paper also aims to generate in depth and complete detail of the Ijarah service and the involved service cocreators and their roles. For ethical reasons the data is anonymized.

\section{Findings}

The narrative interview of an Ijarah manager is divided into thirty-two mean- 
ingful episodes to understand the real Ijarah service creation process. Each episode of the service covers an integrated part of the service process in which at least two roles interact to co-create a part of the whole service. These episodes are developed based on an in-depth interview with the Ijarah manager about a real Ijarah case in Pakistan and some supporting documents that demonstrated different steps of the service. Table 2 summarizes these service episodes. An episode, as used in dramas and documentaries, is a particular scene of a service in which multiple parties interact to create a part of the whole service. A whole service consists of multiple episodes that lead to the achievement of objective set for the service. In the Ijarah case the objective set was to lease a vehicle to the customer.

Table 2: Service Episodes in an Auto Ijarah Lease

\begin{tabular}{|c|c|}
\hline Ep. No. & Description \\
\hline 1. & $\begin{array}{l}\text { The client visited the bank and asked for help regarding auto leasing, he met with Ijarah } \\
\text { Manager (IM) }\end{array}$ \\
\hline 2. & $\begin{array}{c}\text { IM analysed the client's need and affordability and suggested appropriate type of auto } \\
\text { lease. }\end{array}$ \\
\hline 3. & The client prepared the documents required for the evaluation of the case \\
\hline 4. & $\begin{array}{l}\text { The client delivered the documents and deposited processing fee. IM checked the docu- } \\
\text { ments, cashier credited bank account for the processing fee }\end{array}$ \\
\hline 5. & $\begin{array}{l}\text { The IM acquired identify verification of the client through regional coordinator from } \\
\text { the national identity verification authority }\end{array}$ \\
\hline 6. & $\begin{array}{l}\text { The IM acquired credit information report of the client through regional coordinator } \\
\text { from the central bank. }\end{array}$ \\
\hline 7. & IM acquired data check report of the client through head office coordinator \\
\hline 8. & $\begin{array}{l}\text { IM acquired the verifications of the submitted documents from an outside verification } \\
\text { agency }\end{array}$ \\
\hline 9. & IM prepared the case proposal and filled application forms \\
\hline 10. & The hub manager reviewed the case proposal and made some quarries from the IM \\
\hline 11. & The branch manager reviewed the case proposal and documents and made quarries \\
\hline 12. & The area manager reviewed the case proposal sent that to regional coordinator via post \\
\hline 13. & The courier company delivered the post to the regional coordinator \\
\hline 14. & The regional coordinator called the customer and verified the information \\
\hline 15. & The risk assessment manager assessed the case proposal, documents, and made quarries. \\
\hline 16. & The Ijarah product manager reviewed the case and made quarries. \\
\hline 17. & The business manager reviewed the case made quarries. \\
\hline 18. & The consumer finance head reviewed and approved the case. \\
\hline
\end{tabular}




\begin{tabular}{|c|c|}
\hline 19. & The head office coordinator dispatched the case file to the IM with an approval letter. \\
\hline 20. & The courier company delivered the documents to the IM \\
\hline 21. & The IM contacted the customer to read and sign the documents. \\
\hline 22. & $\begin{array}{l}\text { The customer visited the bank, read the approval letter, signed the same, and submitted } \\
\text { car quotation that is obtained from a vendor }\end{array}$ \\
\hline 23 & The credit administrator checked the case with regulations \\
\hline 24. & $\begin{array}{l}\text { Operations manager opened a non-checking account and informed the IM, who in- } \\
\text { formed the customer }\end{array}$ \\
\hline 25. & The customer made the security deposit with cashier \\
\hline 26. & $\begin{array}{l}\text { The credit administrator contacted the Takaful company and tracker company to arrange } \\
\text { takaful coverage and install tracker in the car }\end{array}$ \\
\hline 27. & $\begin{array}{l}\text { Takaful and car tracker companies arranged Takaful and installing tracker in the car, } \\
\text { respectively }\end{array}$ \\
\hline 28. & $\begin{array}{l}\text { The credit administrator manager contacted local registration agent to register the car } \\
\text { with excise department }\end{array}$ \\
\hline 29 & The operations officer prepared the payment document \\
\hline 30 & IM collected the payment document \\
\hline 31 & Customer collected the payment document from IM. \\
\hline 32 & r made payment to the vendor and the vendor delivered the car. \\
\hline
\end{tabular}

As shown in table 2, how various participants in the Ijarah service integrated their actions in multiple episodes (32 in numbers) to complete the Ijarah service and to achieve the set objective of delivering a leased vehicle to the customer. Table 3 further summarizes the Ijarah case data, to have holistic view of who participated in the cocreation of this Ijarah service and what roles did they assume. Column one shows the list individuals who participated in the Ijarah service in terms of performing some actions or resources. Column two categorizes the service creators as customer, bank, aiding parties, and the number of individuals within each. One customer, twelve bank personnel and seven aiding parties are traced collaborating in the Ijarah service. Column three captions the roles that each service cocreator assumed and column four mentions the episodes numbers in which each of the service cocreator participated.

Table 3: Summary of Service Co-creators in the Ijarah Service

\begin{tabular}{|c|c|c|c|}
\hline Count & Service Cocreators & Roles & $\begin{array}{c}\text { Service Episodes Number } \\
\text { (ref. Table 2) }\end{array}$ \\
\hline & Customer & & \\
\hline 1 & Person 1 & Customer, Agent, Lessee & $1,3,4,14,22,25,30,32$ \\
\hline & Islamic Commercial Bank & & \\
\hline
\end{tabular}




\begin{tabular}{|c|c|c|c|}
\hline 2 & Person 1 & Ijarah Manager & $2,4,5,6,7,8,9,21,22,24,30$ \\
\hline 3 & Person 2 & Hub Manager & 10 \\
\hline 4 & Person 3 & Branch Manager & 11 \\
\hline 5 & Person 4 & Area Manager & 12 \\
\hline 6 & Person 5 & Regional Coordinator & 5,6 \\
\hline 7 & Person 6 & Head office Coordinator & $7,14,19$ \\
\hline 8 & Person 7 & Risk Assessment Manager & 15 \\
\hline 9 & Person 8 & Product Manager & 16 \\
\hline 10 & Person 9 & Business Manager & 17 \\
\hline 11 & Person 10 & Consumer Finance Head & 18 \\
\hline 12 & Person 11 & Credit Administrator & $23,26,28$ \\
\hline 13 & Person 13 & $\begin{array}{c}\text { Operations Manager and } \\
\text { Cashier }\end{array}$ & $4,24,25,29$ \\
\hline \multicolumn{4}{|c|}{ Aiding Parties } \\
\hline 14 & Person 1 & Credit Verification Officer & 5,6 \\
\hline 15 & Person 2 & Verification Agent & 7,8 \\
\hline 16 & Person 3 & $\begin{array}{l}\text { Takaful Agent and Tracker } \\
\text { Installer }\end{array}$ & 26,27 \\
\hline 17 & Person 4 & Postal Currier & 13,20 \\
\hline 18 & Person 5 & Vender & 31 \\
\hline 19 & Person 6 & Excise Officer & 28 \\
\hline 20 & Person 7 & Local Registration Agent & 28 \\
\hline 21 & Person 8 & Courier & 13,20 \\
\hline
\end{tabular}

As the data confirms that the Ijarah service is co-created by the customer, the bank, and the aiding parties. The abstract role of a bank is further divided and assigned to eighteen individuals within a bank and seven outside aiding parties. The Ijarah service is co-created because the actions takers towards the objective of service do not just belong to the banks but customer and parties outside of bank also take part in the creation of overall service.

The data also, interestingly, shows that the individuals, when assigned with roles; used the models of their own or their own companies to create their roles during the service cocreation. This is an important insight as this reflects that designing of an IFS is not just limited to the product development department, rather the people at operations design their roles or part of it at time when they execute the designs of IFS. Thus, the over design expands differently with each of its application. 
The service design starts when the Islamic banking division provides model contracts, which a bank adapts into different products. As the design goes towards application, the customer and supporting parties, who contribute in the service, also add parts to the design for their roles in the service. For, instance the Takaful Company in episode 27 collaborated in the Ijarah case and integrated its Takaful policy design with the Bank's Ijarah design, thus the holistic service is co-designed, in essence. This is an in integration of Takaful with the Ijarah and the service model of Tracker Company as well. This, in other words, means that the service co-creators not only co-create the real service but also co-design that, at least, in different parts of the service. Co-designing is different from cocreation of service, because a design is more concerned with the documents and the plans of service actions, whereas the service creation is the enactment of actual actions that people take in the situations to constitute the service as directed by the design. This co-designing of various IFS can enhance value propositions for the market as each designer who integrates its design to the holistic service design actually comes up with at least one additional value proposition for the customer and other stakeholders within the system. Thus, a collaborative design can potentially be worthier in terms of its value for the customer and market as whole.

A change of perspective on the data of Ijarah case, can also give us a view that the various participants actually take benefit of the service of other co-creating partners. For instance, in the Ijarah case, episode number twenty-eight, the service of local agent and excise officer are actually consumed by the customer and the bank together, thus conventionally assumed service creators are found consumers of the service in various parts of the service. This evidence suggests that in some episodes various service creators along with cocreation of service; they somehow co-consume the service or the benefit that the service creates. The value created by each collaborator is consumed by the peer collaborators and vice versa. This consumer role of each participant enhances and tightens the collaboration as each participant sees its share in the output of a service or part of it.

This segregation and individual analysis of the roles create an opportunity to see how the Ijarah involves some different roles that normally do not exist in a conventional lease. For, instance the ownership of the auto remains with the bank till maturity date. The rental is only started when the vehicle is delivered. This is mainly because the rental is attached with its usufruct of the vehicle not with the amount invested by the bank. Similarly, the customer role as agent of the bank to purchase the vehicle also does not exist within conventional lease. These additional roles on one hand transfer the ownership risk from customer to the bank but on the other hand cause increase in documentation, process cost and time as the bank, client, 
and other service collaborating parties are to integrate additional roles and resources. Therefore, Islamic financial services are normally considered inefficient compared to conventional financial services.

To sum-up, the findings of the Ijarah case presented in this paper show that the real service is co-created by the customer, the service organisation (Islamic bank), and the aiding parties. Each of these service cocreators further divides its roles into sub roles assigned to individuals e.g., the personnel of the bank. The service is termed co-created because each participant contributes and integrates its actions and resources with that of others. It is also found that service is co-designed and co-consumed by the customer, bank, and the aiding parties.

\section{Discussion and Implications for Islamic Banking and its Marketing}

The phenomenon of service co-design, cocreation, and co-consumption are reasonably novel for the literature of Islamic banking and it's marketing. The current Islamic finance models (IFMs) such as partnership, sale, lease, and others are primarily based on ontological and epistemological sources of Shari'ah (e.g., Ahmed, 2011; Ayub, 2008; Iqbal \& Mirakhor, 2008; Usmani, 2002). The models, as normative models do, provide structures based on the norms of Shari'ah related the financial and physical assets' transactions. These economic and financial models provide consideration to the intangible service cocreation interactions and experiences. In other words, the importance is on the legal form rather substance that emerges as consequence of the application of these IFMs (Jan, Ullah \& Asutay 2015). In other words, the argument is that there is way too much focus on whether individual documents are Shari'ah complaint instead of focusing on the documentation as a whole to meet certain objectives of Shari'ah (Maqasid al-Shari'ah). Service is much larger and substance-focused than structure-focused, as articulated in IFMs. The focus in service make the Shari'ah compliance in more experiential, which interns, make the stakeholders to feel and experience the Shari'ah compliance, thus enhance their trust on the Shari'ah compliance in the actual application of IFMs and achievement of objectives.

The identification of multiple roles and its segregation can enhance the bankers and regulators vision to see whether each role on its own and in integrated form is Shari'ah compliant or not. For instance, isolated analysis of the vehicle supply, Takaful, and agency roles can better be designed if they are accepted to be part of the IFM. Current IFMs do not provide a holistic perspective and do not consider these collaborative roles as part of their product design.

This paper has significant implications for IFMs theory because it attempts to establish an alternative service perspective, which challenges the sufficiency of IFMs, 
in terms that these models do not cover holistic co-created service that in reality occur in practice. Service literature and empirical evidence within IFMs provide evidence for the service cocreation and collaboration that create a holistic Islamic banking market.

The synthesis of concepts such service cocreation and Islamic juridical principles can bring up viable solution models for how holistic Islamic banking services can be designed to effectively cover the service cocreation and thus adheres to Shari'ah both in legal form and in the substance of the actual service that occurs through application of IFMs. Such Islamic banking service will be more acceptable to the co-creating parties within market as it is market faced and take into account all the contributing parties that emerge within market to create each service process.

This paper, therefore, provides a baseline towards development of Islamic service models, which can complement the current IFMs to holistically capture both economic transactions and service elements, currently prevailing in the Islamic banking market. The collaborative thinking of IFS broaden the visualization power of product developers at Bank and regulators and through it they can better comprehend a service that emerges not just in a single entity rather within the domain of multiple collaborating agents.

The phenomenon of service cocreation is important in the current context of Islamic banking service quality enhancement and efficiency as well. As this paper suggests, that an Islamic Bank must be in close collaboration to co-design, co-create, and consume service, hence it is highly likely that the resultant service will also enhance customer satisfaction and service quality. As the customers' satisfaction is crucial for the overall service quality of Islamic banks (Hossain \& Leo, 2009). For such enhancement of quality, the personnel from service organisation (e.g., an Islamic bank), customer, and supporting entities need to more closely integrate their competencies to create artefacts and actions that could satisfy each other's needs compliant to Shari'ah. Such integration and application of competence for each other is the service (Lusch \& Vargo, 2006) and it can only be enabled through some confidence and trust building measures so that the integration and collaboration can continue for longer and cause sustainability of the service cocreators as a holistic service community. Such trust among the participants of an Islamic banking service can create a social capital and can enhance the overall efficiency of the Islamic banks (E.g., Ibrahim \& Mirakhor, 2015). This will be a move towards a Shari'ah based banking community perspective from the traditional bank and customer perspective.

The phenomenon of service co-designing and co-creating the service is of practical importance too, particularly in the current information age, where Islamic banks, Takaful companies, and other service organisations such as credit agencies and in- 
terbank networks are integrating their actions and resources to co-create services. In this scenario, future research in the direction of service cocreation can bring useful mechanisms that can solve practical integration and collaboration issues which are currently faced by the Islamic banks and regulators.

\section{Conclusion}

This paper attempts to propose and evaluate a potential alternative philosophical base for conceptualizing Islamic banking as collaborated and co-created service, which can complement the current Islamic banking paradigm based on economics and Shari'ah. Such approach toward designing and developing financial contracts in Islamic banking system is the first step toward more efficient based design of products. In this case study, we are able to show that how different players are involved and contribute to the creation of Ijarah service, who are not only the co-creators but they are also the co-designers and co-consumers of the same Islamic banking service. This approach helps not only to design products from the financial and economic models' perspectives, which is the current norms of Islamic financial industry, but also provides consideration to propose Islamic finance as collaborative service. This is considered an important step for moving to Islamic based finance from Islamic compliant financing, because this approach enables us to observe not only the economic transaction but also the intangible service elements in a holistic Islamic banking service. This calls for collaborative service better suits to the orientation of Shari'ah, which proposes more collaborative and holistic efforts. Furthermore, collaborative service based approach to Islamic banking can be applied on other financial contracts to structure them more efficiently.

\section{References}

Ahmed, H. (2011). Product development in Islamic banks. Edinburg: Edinburgh University Press.

Ashfaq, A., Malik, M. I., \& Humayoun, A. A. (2010). Banking developments in Pakistan: A journey from conventional to Islamic banking. Journal of Social Sciences, 17(1), 12-17.

Ayub, M. (2008). Understanding Islamic finance. Chicester: John Wiley.

Boyce, C., \& Neale, P. (2006). Conducting in-depth interviews: A guide for designing and conducting in-depth interviews for evaluation input. Watertown MA: Pathfinder International.

Chase, R. B., \& Tansik, D. (1983). The customer contact model for organization designing. Management Science, 29(9), 1037-1050.

Creswell, J. W. (Ed.). (2009). Research design: Qualitative, quantitative, and mixed methods approach (3 $3^{\text {rd }}$ ed.). Thousand Oaks, CA: Sage. 
Dar, H. A., \& Presley, J. R. (1999). Islamic finance: A western perspective. International Journal of Islamic Financial Services, 1(1), 1-9.

El-Gamal, M. (2008). Incoherence of contract-based islamic financial jurisprudence in the age of financial engineering. Wisconsin International Law Journal, 25(4), 606-623.

Grönroos, C. (Ed.). (2000). Service Management and marketing: A customer relationship approach (2 ${ }^{\text {nd }}$ ed.). Chichester: Wiley.

Hossain, M., \& Leo, S. (2009). Customer perception on service quality in retail banking in Middle East: The case of Qatar. International Journal of Islamic and Middle Eastern Finance and Management, 2(4), 338-350.

Iqbal, Z., \& Mirakhor, A. (2008). An introduction to islamic finance theory and practice. Lahore: Vanguard Books.

James, C. (1987). Some evidence on the uniqueness of Bank loans. Journal of Financial Economics, 19(2), 217-235.

Jan, S., Ullah, K., \& Asutay, M. (2015). Knowledge, work, and social welfare as islamic socioeconomic development goals. Journal of Islamic Banking and Finance, 32(3), 9-19.

Lusch, R. F., \& Vargo, S. L. (2006). The service-dominant logic of marketing: reactions, reflections, and refinements. Marketing Theory, 6(3), 281-288.

Maglio, P. P., Vargo, S. L., Caswell, N., \& Spohrer, J. (2009). The service system is the basic abstraction of service science. Information Systems and e-business Management, 7(4), 395-406.

Ng, A., Ibrahim, M., \& Mirakhor, A. (2015). On building social capital for Islamic finance. International Journal of Islamic and Middle Eastern Finance and Management, 8(1), 2-19.

Polkinghorne, D. E. (1988). Narrative knowing and the human sciences. New York: State University of New York Press.

Sampson, S. E. (2010). Visualizing service operations. In P. P. Maglio, C. A. Kieliszewski, \& J. C. Spohrer (Eds.), Handbook of service science: Research and inoovations in the service economy (pp. 107-131). New York: Springer.

Sampson, S. E. (2012). Visualizing service operations. Journal of Service Research, 15(2), 182-198.

Sangiorgi, D. (2009). Building up a framework for service design research. 8th European Academy of Design Conference, (pp. 1-3). Aberdeen.

Shostack, L. G. (1982). How to design a service. European Journal of Marketing, 16(1), $49-63$.

Siddiqi, M. N. (2006). Islamic banking and finance in theory and practice: A Survey of State of the Art. Islamic Economic Studies, 13(2), 1-48.

Stoecker, R. (1991). Evaluating and rethinking the case study. The Sociological Review, 39(1), 88-112. 
Thomas, G. (2011). A typology for the case study in social science following a review of definition, discourse, and structure. Qualitative Inquiry, 17(6), 511-521.

Ullah, K. (2014). Adaptable service-system design: An analysis of shariah finance in Pakistan. Doctoral Dissertation, London: Brunel University.

Ullah, K., \& Al-Karaghouli, W. (2017). Understanding islamic financial services: Theory and practice. London: Kogan Page Publishers.

Ullah, K., Jan, S., Khan, Z. (2017). Islamic working capital finance through Murabahah

for a construction company. Journal of Islamic Business and Management, 7(1), (In print).

Usmani, M. T. (2002). Introduction to islamic finance. The Hague: Kluwer Law International.

Vargo, S. L., \& Akaka, M. A. (2012). Value cocreation and service systems (re) formation: A service ecosystems view. Service Science, 4(3), 207-217.

Vargo, S. L., \& Lusch, R. F. (2004). Evolving toward a new dominant logic for marketing. Journal of Marketing, 68(1), 1-17.

Vogel, F. E., \& Hayes, S. L. (1998). Islamic law and finance: Religion, risk, and return. The Hague: Kluwer Law International.

Wilson, R. (2002). Economic development in the Middle East. London: Routledge.

Yin, R. K. (2003). Case study research: Design and methods (3 $3^{\text {rd }}$ ed.). London: Sage Publications. 
